LIFE SCIENCES Vol. 6, pp. 1245-1252, 1967. Pergamon Press Ltd. Printed in Great Britain.

THE EFFECT OF PROSTAGLANDINS ON PROTEIN AND NUCLEIC ACID SYNTHESIS

IN A CELL-FREE SYSTEY

R. W. Ruddon* and J. M. Johnson

Department of Pharmacology, The Dniversity of Michlgan Medical School Ann Arbor, Michigan

(Received 20 February 1967; in final form 13 March 1967) THE prostaglandins are famlly of hydroxy unsaturated $C_{20}$ fatty acida which have been classifled Into an $E$ and $F$ series. Six different compounds have been 1solated from varlous natural sources, Including semen, vesicular glands, menotrual fluld, lung, braln, thymus, and 1ris (1). The proataglandins have a varlety of effects on biological systems. Prostaglandin $\mathrm{E}_{1}$, for example, inhibita the tone of vascular, resplratory, and reproductive smooth muscle, Inhibits the mobllization of fatty acids from adipose tisaue In response to catecholamines, and depresses the central nervous system $(1,2)$.

On the basis of present evidence it seems that the prostaglandins are not circulating hormones and that they may act intracellulary as co-enzyoes or as a factor in cellular control mechanlsms (1). If this were true, these agents would be expected to affect biosynthetic mechanisms. The present Investigation was designed to examine the effects of two prostaglandins, PEE $_{1}$ and PGF ${ }_{1 \alpha}$, on protela and nuclelc ac1d synthesis in a cell-free system derived from E. coll B cells.

\title{
Mater1als and Methods
}

Egcherichla coli (strain B) were grown at $37^{\circ}$ in a glucose enriched Difco broth (3) and harvested in the early $\log$ phase of growth. The cells

*ost-Doctoral Scholar of the American Cancer Society. Research supported by USPAS Grant CA-02992-11. 
were disrupted, extracted, and s-30, ribosomal, and s-100 fractions prepared by the methods of Nirenberg and Natthael (4). Prostaglandins $P_{1}$ and $P G P_{1 \alpha}$ were obtained in purified form from the Upjohn Company (Ralamazoo, Michigan). Stock solutions were prepared by dissolving $1 \mathrm{mg}$ prostaglandin In $0.1 \mathrm{ml} 95 \%$ ethanol and $0.9 \mathrm{ml}$ of $0.02 \%$ sodium carbonate solution. Dilutions of the stock solution were made with distilled weter, and the final $\mathrm{pH}$ of the solutions was 6-7. It should be noted that these solutions of prostaglandins lost their activity in the cellfree syatem after belng stored at $0-4^{\circ} \mathrm{C}$ for $12-14$ days.

The reaction mixture used to determine effects of the agents on protein synthesis contalned the following in $\mu m$ mes/ml unlese otherwise noted: 50 Iris - HCl, pH 7.8; 15 magnesium acetate; $70 \mathrm{KC1} ; 4.2$ B-gercaptoethanol; 2.5 PEP; 1.0 ATP; 0.3 GTP; 0.05 each of 19 amino actds; $0.1 \mu$ Curle phenylalanine $-{ }^{14} \mathrm{C}$ (opeciflc activity $\left.=7.0 \mathrm{ucurles} / \mathrm{mmole}\right) ; 20 \mu \mathrm{g}$ pyruvate kinase; 1.5-2.0 mg S-30 proteln, and 50 48 poly $U$. $P G E_{1}$ and $P G F_{1 \alpha}$ were added In $0.05 \mathrm{ml}$ volumes. Total volume of the reaction mixtures vas $0.3 \mathrm{ml}$. The reaction mixtures vere incubated at $37^{\circ}$ for $40 \mathrm{~min}$, , and the reactions were stopped with 3 ml of cold $10 \%$ trichloroacetic acid. Washing and removal of the nucleic acids from the prectpltates were performed by a modification of the method of Siekevitz (5). The protein precipltate in TCA was poured on a Milifpore filter $(0.45 \mu$ pore size) and washed with $5 \%$ TCA. The filters were dried and placed In counting vials. Toluene phosphor (10 ml) was added, and the samples counted in Packard Tri-Carb IIquid Scintillation Spectrometer. Results were calculated as counts per minute (CFM) per reaction mixture and all determlnations were done in duplicate.

In sowe of the experiments the washed ribosomes and the S-100 supernatant fractions were preincubated with various concentrations of prostaglandins prior to assay of poly $\mathrm{U}$-directed phenylalanine - ${ }^{14} \mathrm{C}$ Incorporation as above. The effect of prostaglandins on the binding of ${ }^{3} H$-poly $U$ to 
rlbosomes was determined by the method of Moore (6). The effect of prostaglandins on the synthesis of phenylalanyl - ${ }^{14} \mathrm{C}$ tRNA was determined by adding the agents $(0.05 \mathrm{ml})$ to an $0.25 \mathrm{ml}$ reaction mixture containing $1.0 \mathrm{mg}$ "str1pped" sRNA; $0.8 \mu$ moles ATP; $9 \mu$ moles PEP; $2 \mu g$ pyruvate kinase; 14 mumoles of 19 amino acids; $14 \mu$ moles Tris-HCl, pH 7.2; $0.125 \mu$ Curtes phenylalantne $-{ }^{14} \mathrm{C}$ (sp. act. $222 \mathrm{mc} / \mathrm{mmole}$ ); and $0.3 \mathrm{mg}$ s-100 proteln. The reaction mixtures were Incubated for $12 \mathrm{~min}$. at $37^{\circ}$. The reactions were otopped with 5\% TCA; and the mixtures were poured on Mililpore filters, washed with $2.5 \%$ TCA, dried, and counted as above. It was demonstrated that most of the labeled amino acid was in the RMA fraction and not incorporated into protein, as heating the mixtures at $80-90^{\circ}$ in $5 \%$ TCA prior to filtration removed more that $97 \%$ of the radioactivity.

The incubation mixture employed for determining the effect of prostaglandins on uridine $-{ }^{14} \mathrm{C}$ incorporation into RM contained the followng (in Hmoles/ml unless otherwise specif1ed): $50 \mathrm{Trls}$ - $\mathrm{HCl}$, pH 7.8; 15 magnesium acetate; $70 \mathrm{KCl}$; $4.2 \beta$-mercaptoethenol; $2.5 \mathrm{PEP}$; $0.5 \mathrm{ATP}$; and 0.2 each of GIP and CTP; $20 \mu \mathrm{g}$ pyruvate kinase; $0.1 \mu \mathrm{C}$ of uridine $-{ }^{14} \mathrm{C}$ (op. act. $30 \mathrm{mC} /$ umole); and $1.3 \mathrm{mg}$ s-30 protein. The same reaction mixture was used to measure DNA synthesis with the exception that $0.2 \mu$ mole/mi each of dATP, dGTP, dCTP were employed, and thymidine $-{ }^{14} \mathrm{C}$ (sp. act. $30 \mathrm{mc} / \mathrm{mole}$ ) was used in place of uridine. In some experiments $84 \mu \mathrm{g}$ of "primer" DiA (calf thyms) was added. The reaction mixtures $(0.3 \mathrm{ml})$ were incubated for $40 \mathrm{~min}$ at $37^{\circ}$, and the reaction. stopped with $3 \mathrm{ml}$ cold $5 \% \mathrm{TCA}$. The prectpitates were filtered on Mllipore filters, washed with cold $2.57 \mathrm{TCA}$, and counted as above.

\section{Requlte}

The effects of the prostaglanding $P_{1}$ and $P G F_{1 \alpha}$ on protein synthesis In the s-30 fraction from E. col1 is shom in Table 1. 


\section{TABLE 1}

Effect of Prostaglandins $E_{1}$ and $F_{1 \alpha}$ on Poly U-Directed Incorporation of Phenylalanine - ${ }^{14} \mathrm{C}$ 1nto Protein in the s-30 Fraction from E. Coll

\section{Modifications}

Complete

-Poly $U$

+PGE $_{1}$

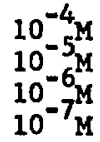

$+P_{1 \alpha}$

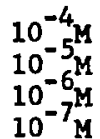

Deproteinized at zero time
$\%$ Decrease

CPM

13,952

3,064

14,781

13,214

12,067

12,081

14,193

13,241

12,453

11,965

2,622
Erom Control

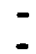

$-$

7

17

17 
TABLE 2

Effects of Prostaglandins on the Activity of Ribosomes and S-100 Fraction in Poly U-DIrected Polyphenylalanine Synthesis*

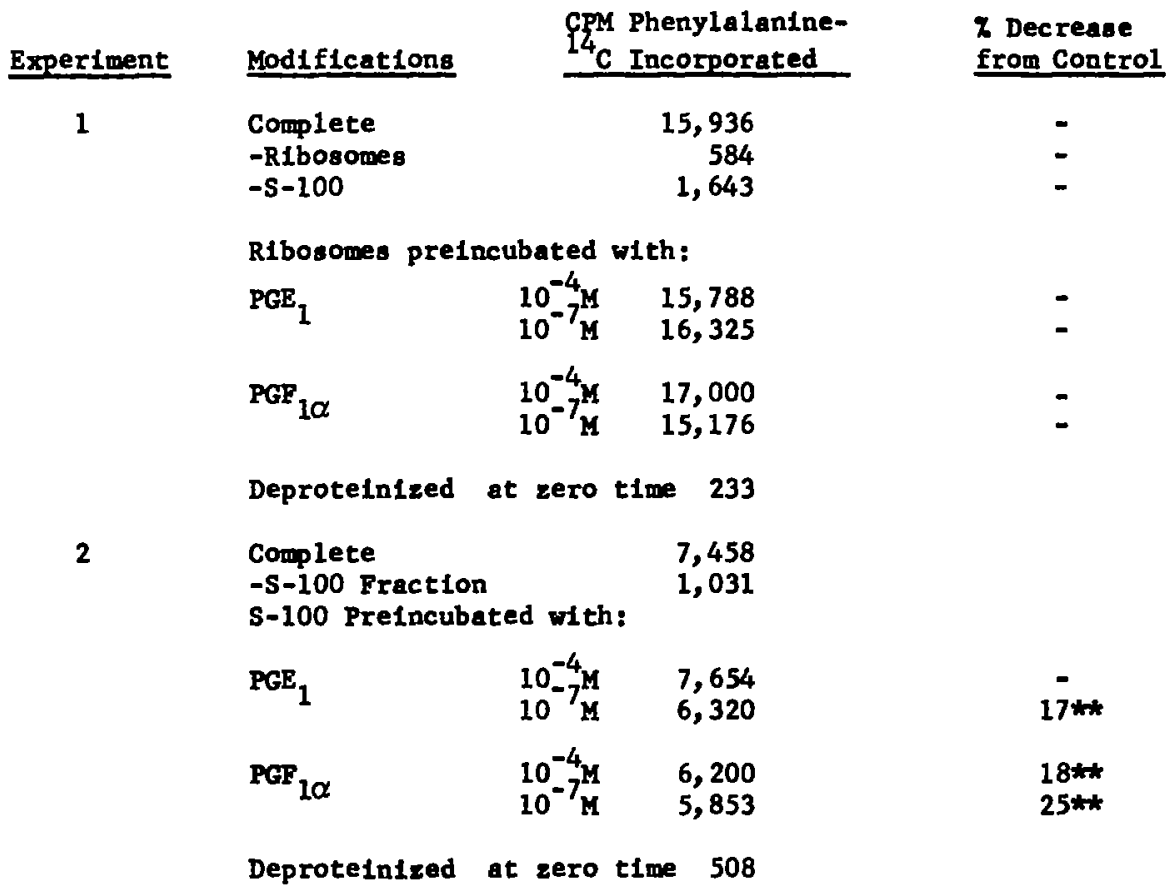

*RIbosomes and the S-100 fraction were preincybated with the prostaglanding

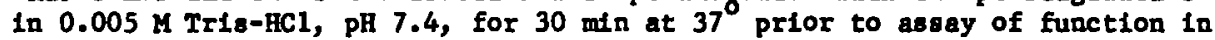
poly U-directed protela syntheais.

**Repetition of this experiment $(n=4)$ demonstrated these changes to be igalficant ( $p<0.01)$.

effect on the binding of ${ }^{3} H$-poly $U$ to ribosomes nor the binding of phenylalanyl - $c^{14}$ - tRKA to a ribosome-poly $U$ complex.

Table 4 shows the effect of these agents on DW synthesis in the E. coll cell free system. Concentrations of $10^{-4} \mathrm{M}$ and $10^{-7} \mathrm{M}$ of both 
TABLE 3

Effect of Prostaglandins on the Synthesis of Phenylalanyl $-{ }^{14} \mathrm{C}-\mathrm{tRNA}$ In the S-100 Fraction of E. Col1

Yodifications

Complete

$-s-100$

Complete (Heated to $90^{\circ}$ for $10 \mathrm{~min}$ in $2.5 \% \mathrm{TCA}$ )

PFE $_{1}$

+PGF $_{1 \alpha}$

$$
\begin{aligned}
& 10^{-4} \mathrm{M} \\
& 10^{-7} \mathrm{M} \\
& 10^{-4} \mathrm{M} \\
& 10^{-7} \mathrm{M}
\end{aligned}
$$

CPM

37,261

1,047

1,263

38,467

37,510

37,310

36,675

TABLE 4

\begin{tabular}{|c|c|c|c|}
\hline Expertment & Modificatione & $\begin{array}{l}\text { CPM Thymidine }-{ }^{14} \mathrm{C} \\
\text { Incorporated }\end{array}$ & $\begin{array}{l}\text { \% Decrease } \\
\text { from Control }\end{array}$ \\
\hline \multirow[t]{3}{*}{1} & \multicolumn{2}{|c|}{$\begin{array}{c}\text { Complete (no exogenous } \\
\text { Dhu primer) }\end{array}$} & - \\
\hline & $+\mathrm{PGE}_{1}$ & $\begin{array}{l}12,402 \\
12,056\end{array}$ & - \\
\hline & $+P G P_{1 \alpha}$ & 10,948 & - \\
\hline \multirow[t]{3}{*}{2} & \multicolumn{2}{|c|}{ Complete (with DA priner) $* 19,028$} & - \\
\hline & $+\mathrm{PGE}_{1}$ & $\begin{array}{l}13,134 \\
13,924\end{array}$ & $\begin{array}{l}31 \\
27\end{array}$ \\
\hline & $+\mathrm{PGF}_{1 \alpha}$ & $\begin{array}{r}12,011 \\
9,671\end{array}$ & $\begin{array}{l}37 \\
50\end{array}$ \\
\hline
\end{tabular}

Effect of Prostaglandins on DIA Synthesis in an ㅌ. Coli Ce11-Free System

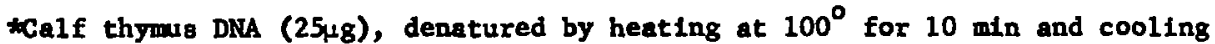
rapidly, was added to the $0.3 \mathrm{ml}$ reaction mixture, and incorporation of thymidine - $14 \mathrm{C}$ into DKA vas determined in duplicate samples.

prostaglandins inhibited exogenous DM-directed thymidine $-{ }^{14} \mathrm{C}$ incorporation Into DKA; however, DNA synthesis directed by endogenous DNA template was not Inhibited. In addition, the prostaglandins had no significant effect on the Incorporation of uridine $-{ }^{14} \mathrm{C}$ into RAA as directed by endogenous template (Table 5). 
TABLE 5

Effect of Prostaglandins on UrIdine $-{ }^{14} \mathrm{C}$ Incorporation Into RNA In an E. Col1 Cell-Free Systeru*

Modifications

Complete

$+\mathrm{PGE}_{1}$

$10^{-4} \mathrm{M}$

2846

$10^{-5} \mathrm{M}$

$+P_{1 \alpha}$

$10^{-4}$

*No exogenous DNA primer was added to the oystem

\section{Discusstion}

The effects of the prostaglandins $\mathrm{PGE}_{1}$ and $P G F_{1 \alpha}$ on protein and nucleic acId synthesis in an E. coli cell-free gystem have been examfned in order to ascertain whether these agents might have a function in the intracellular control of these synthetic mechanisms. It was demonstrated that these agents have a slight inhibitory effect on protein synthesis, which was evident only at 10 concentrations, and that the Inhibitory effect was produced in the fraction of the cell-free syotem containing the protein-synthesizing enzymes (S-100 fraction). The reason for the apparent dual mechanism of action of these compounds is not yet evident. Perhaps low concentrations partially inhlbit the function of an enzyme necessary for proteln synthesis, and higher concentrations inhibit the enzymatic degradation of messenger RNA, thereby overriding the small inhlbitory effect. The prostaglandins had no effect on the binding of poly $\sigma$ to ribosomes, the binding of phenglalanyl tRKA to a poly U - ribosome complex or the synthesis of phenylalanyl - tRRA, suggesting that these agents act on the polymerization of amloo acids into polypeptide. The lack of effect of the prostaglandins on DKA or RHA synthesis directed by endogenous template auggests that the E. Colf DNA Is In 
such a configuration that interaction with these agents does not occur, whereas exogenous DNA may interact with the agents.

In summary, it appears that the prostaglandins $P_{1} E_{1}$ and PGF $1 \alpha$ have only slight effects on the synthesis of macromolecules in a cell-free system. If these agents have a function in intracellular control mechanisms, it may be at some other level of integration of cellular activity, or effects on biosynthetic mechanisms may only be evident in certain target tissues in vivo.

\section{Acknowledgements}

The authors wish to thank Linda Gal11gher for her excellent technical assistance and Dr. James R. Weeks and Dr. John E. Plke of the Upjohn Company for supply1ng tine prostaglandins.

\section{References}

1. E. W. Horton, Experientia 21, 113 (1965).

2. S. Bergstrom, Recent Progress 1n Hormone Research 22, 153 (1966).

3. A. Tissleres, J. D. Watson, D. Schlessinger and B. R. Hollingworth, I. Mol. B101. 1, 22 (1959).

4. M. W. N1renberg and J. H. Matthae1, Proc. Nat1. Acad. Sc1. U. S. 47, 1588 (1961).

5. P. Siekevitz, J. Biol. Chem. 195, 549, (1952).

6. P. Moore, I. Mol. B101. 18, 8 (1966). 